\title{
Profil Kesulitan Mahasiswa dalam Menyelesaikan Soal Induksi Matematika Ditinjau dari Gaya Belajar
}

\author{
Ernawati
}

ernawati@unismuh.ac.id

\begin{abstract}
ABSTRAK
Penelitian ini bertujuan untuk mengetahui profil kesulitan Mahasiswa dalam menyelesaikan soal induksi matematika ditinjau dari gaya belajar visual, auditori dan kinestetik. Penelitian ini merupakan penelitian deskriptif dengan pendekatan kualitatif. Data yang diolah adalah data gaya belajar dan data kesulitan mahasiswa dalam menyelesaikan soal induksi matematika. Berdasarkan olahan data tersebut, diperoleh bahwa mahasiswa yang gaya belajar visual mengalami kesulitan dalam mentransfer pengetahuan dan kemampuan bahasa matematika yang kurang, Mahasiswa yang bergaya belajar auditori mengalami kesulitan pada kelemahan dalam berhitung dan kemampuan bahasa matematika yang kurang, dan mahasiswa yang bergaya belajar kinestetik tidak memiliki kecenderungan kesulitan dalam mengerjakan soal. Adapun kesulitan yang paling dominan adalah kemampuan bahasa matematika yang kurang.
\end{abstract}

Kata kunci: Profil, Kesulitan, Induksi Matematika dan Gaya Belajar

\section{PENDAHULUAN}

Pendidikan merupakan salah satu kebutuhan yang harus dipenuhi oleh semua individu. Pendidikan merupakan usaha sadar untuk menyiapkan Mahasiswa melalui kegiatan bimbingan, pengajaran, dan latihan untuk memenuhi peranannya di masa yang akan datang. Menurut Kamus Besar Bahasa Indonesia $(\mathrm{KBBI})$, pendidikan diartikan sebagai proses pembelajaran bagi individu yang bertujuan untuk mencapai pengetahuan serta pemahaman yang lebih tinggi mengenai objek-objek tertentu

Proses belajar dan pembelajaran adalah suatu hal yang harus diperhatikan dan tidak boleh diabaikan oleh Mahasiswa dalam dunia pendidikan. Mahasiswa dikatakan sudah belajar apabila terdapat perubahan dalam tingkah lakunya, tingkah laku yang dimaksud disini adalah menyangkut perubahan Kognitif (Pengetahuan) dan Psikomotorik (Keterampilan) maupun dalam bentuk sikapnya. Hal ini sejalan dengan 
pendapat dari W.S. Winkel yang menyatakan bahwa belajar adalah suatu aktivitas mental atau psikis yang berlangsung pada interaksi aktif dengan lingkungan yang menghasilkan perubahan dalam pengetahuan, pemahaman, keterampilan dan nilai dari sikap (Kristanti, 2017; 1)

Matematika adalah salah satu mata pelajaran yang diajarkan kepada Mahasiswa. Tentunya setiap mata pelajaran yang diajarkan kepada Mahasiswa memiliki karakteristik masing-masing. Begitupun dengan matematika, salah satu karakteristik dari matematika menurut Soedjadi adalah memiliki objek yang abstrak (Adhitya, 2015:24). Sebagai ilmu dasar, matematika juga sangat berperan dalam segala bidang pembelajaran lainnya oleh karenanya sudah sepantasnya apabila matematika diberikan perlakuan yang khusus dalam proses pembelajarannya agar Mahasiswa dapat memahami dengan baik konsep maupun prinsip dari matematika itu sendiri.

Pembelajaran matematika di sekolah dimaksudkan untuk mencapai tujuan sebagai berikut:(a) memahami konsep matematika, (b) menggunakan penalaran, (c) kemampuan memecahkan masalah, (d) mengkomunikasikan gagasan dengan simbol, dan (e) memiliki sikap menghargai kegunaan matematika dalam kehidupan (Depdiknas, 2006, p.346), namun pada realita yang terjadi masih banyak Mahasiswa yang mengalami kesulitan dalam pembelajaran sehingga untuk mencapai apa yang ditujukan oleh pendidikan matematika terasa sangat mustahil apabila tidak secepatnya dipecahkan.

Salah satu materi dalam pembelajaran matematika yang sulit dipelajari oleh Mahasiswa adalah induksi matematika, induksi matematika adalah suatu cabang ilmu tentang pembuktian suatu pernyataan dalam matematika, materi ini pertama kali diperkenalkan kepada Mahasiswa.Untuk dapat menguasai materi tersebut dibutukan penalaran yang tinggi dari Mahasiswa, menguasai teknik manipulasi aljabar dalam matematika dan wajib menguasai dasar-dasar dari matematika seperti perhitungan, sifat-sifat operasi dan sebagainya. Dari pembahasan diatas dapat kita simpulkan bahwa pada saat Mahasiswa tidak dapat menguasai materi-materi sebelumnya yang berhubungan dengan materi 
tersebut maka Mahasiswaakan kesulitan dalam mempelajari materi induksi matematika

Menurut Hamalik kesulitan belajar adalah hal-hal atau gangguan yang mengakibatkan kegagalan atau setidaknya menjadi gangguan yang dapat menghambat kemajuan belajar (Kristianti, 2016:1), dalam penelitian ini yang peneliti mengambil kesulitan yang di kemukakan oleh Martini (2013:188) sebagai berikut(1) Kelemahan dalam berhitung, (2) Kesulitan dalam mentransfer pengetahuan, (3) Pemahaman bahasa matematika yang kurang dan (4) Kesulitan dalam persepsi visual

Kesulitan yang sering dialami oleh Mahasiswa yaitu kesulitan saat mengerjakan soal karena kurang mampu memahami maksud soal dan kebingungan saat menentukan operasi hitung yang akan dipakai. Selain itu, Mahasiswa sering melakukan kesalahan saat menghitung, apalagi menghitung operasi perkalian dan pembagian dengan cara bersusun panjang. Lebih lanjut guru tersebut mengatakan bahwa setiap Mahasiswa memiliki kesulitan dalam mengerjakan soal yang berbeda-beda, hal ini di akibatkan oleh gaya belajar Mahasiswa dalam menangkap pembelajara juga berbeda beda.

Gaya belajar menurut Gunawan(Afif dkk, 2016:329)merupakan cara yang lebih disukai dalam melakukan kegiatan berpikir, memproses dan mengerti suatu informasi. Sedangkan menurut Deporter \& Henacky (Afifah, dkk. 2017:7)"gaya belajar terbagi menjadi tiga jenis. Ketiga jenis tersebut ialah gaya belajar visual, auditorial, dan kinestetik. Ketiga jenis gaya belajar tersebut dibedakan berdasarkan kecenderungan mereka memahami dan menangkap informasi lebih mudah menggunakan penglihatan, pendengaran, atau melakukan sendiri". Gaya belajar visual adalah gaya belajar dengan cara melihat, gaya belajar auditori adalah gaya belajar dengan cara mendengarkan dan gaya belajar kinestetik adalah gaya belajar dengan cara bergerak.

Dalam pengerjaan soal matematika ketiga gaya belajar tersebut memiliki kesulitan yang berbeda beda hal ini dikarenakan ketiga gaya belajar tersebut memiliki titik pokus yang berbeda-beda, halinilah yang harusdiketahuiolehseorang guru. Sejalan dengan hal tersebut menurut Bobbi 
de Potter (Yudha dkk, 2017:3) yaitu dengan mengetahui gaya belajar yang berbeda ini telah membantu para guru dimanapun untuk dapat mendekati semua atau hampir semua murid hanya dengan menyampaikan informasi dengan gaya yang berbeda-beda. Hal inilah yang mendorong penulis untuk melakukan penelitian terkait profil kesulitan Mahasiswa dalam mengerjakan soal induksi matematika ditinjau dari gaya belajarnya. Dengan melaksanakan penelitian ini Mahasiswa dapat mengetahui letak-letak kesulitanya dalam mengerjakan soal agar dikemudian hari tidak terjadi hal yang sama dan guru yang bersangkutanjugadapatmenentukancaramengatasihaltersebut.

\section{METODE PENELITIAN}

Penelitian ini merupakan penelitian kualitatif deskriptif yang bertujuan untuk mengetahui gambaran kesulitan Mahasiswa dalam menyelesaikan soal induksi matematika yang ditinjau dari gaya belajar Mahasiswa. Subjek dalam penelitian ini adalah 2 Mahasiswa dari setiap gaya belajar yang berada pada kelas A Angkatan 2017yang memiliki kesulitan yang beragam dan mampu berkomunikasi dengan baik.

Teknik pengumpulan data pada penelitian ini adalah Eksplanasi Sekuensial (The Explanatory Sequential Design). Metode ini digunakan untuk mengetahui kesulitanMahasiswa dalam menyelesaikan soal induksi matematika ditinjau dari gaya belajar. Data tentang gaya belajar diperoleh dari angket gaya belajar dan data berupa kesulitan Mahasiswa dalam mengerjakan soal induksi diperoleh dari tes hasil belajar dan wawancara. Angket gaya belajar dibuat berdasarkan teori dari Deporter \& Henacky(Afifah, dkk. 2017:7), tes hasil belajar dibuat dengan memperhatikan indicator kesulitan belajar menurut Martini dan wawancara yang digunakan adalah wawancara tidak tersruktur, dimana peneliti tidak menggunakan pertanyaan yang telah disusun sebelumnya secara sistematis.

Kemudian dari data yang terkumpul selanjutnya peneliti melakukan analisis sebagai berikut ini (1) gaya belajarMahasiswa ditentukan dari hasil yang paling dominan pada angket gaya belajar, (2) tes hasil belajar di 
analisis menggunakan kesulitan menurut Martini dan (3)Wawancara di analisis dengan tahapan sebagai berikut Reduksi data, penyajian data dan penarikan kesimpulan. Adapun indicator dari kesulitan belajar menurut martini adalah sebagai berikut:

Tabel 1.Indikator Kesulitan Belajar

\begin{tabular}{|c|c|}
\hline Kesulitan belajar & Indikator kesulitan belajar \\
\hline Kelemahan dalam berhitung & $\begin{array}{l}\text { 1. Kesalahan dalam menjumlahkan } \\
\text { dua bilangan contoh : } 2 \mathrm{k}^{3}+3 \mathrm{k}^{2} \\
+\mathrm{k}+6 \mathrm{k}^{2}+12 \mathrm{k}+6=\ldots \\
\text { 2. } \\
\text { Kesalahan dalam mengalikan } \\
\text { dua bilangan yang berbeda } \\
\text { contoh: } \mathrm{n}(\mathrm{n}+1)(\mathrm{n}+2)=\ldots . \\
\text { 3. } \\
\text { Kesalahan dalam } \\
\text { mengkuadratkan suatu bilangan } \\
\text { contoh: }(\mathrm{k}+1)^{2}=\ldots\end{array}$ \\
\hline $\begin{array}{l}\text { Kesulitan dalam mentransfer } \\
\text { pengetahuan }\end{array}$ & $\begin{array}{l}\text { 1. Mahasiswa tidak menjawab } \\
\text { soal, ditentukan dengan } \\
\text { wawancara } \\
\text { 2. Kesalahan dalam menggunakan } \\
\text { rumus } \\
\text { 3. Kesalahan dalam memahami } \\
\text { maksud soal } \\
\text { 4. Kesalahan dalam mensubsitusi } \\
\text { apa yang diketahui soal dalam } \\
\text { rumus, contoh: mensubsitusi } \\
\text { n=k kedalam pernyataan } \mathrm{n}=\mathrm{k}+1\end{array}$ \\
\hline $\begin{array}{l}\text { Pemahaman Bahasa matematika } \\
\text { yang kurang }\end{array}$ & $\begin{array}{l}\text { 1. Mahasiswa tidak menjawab } \\
\text { soal, ditentukan dengan } \\
\text { wawancara } \\
\text { 2. Kesalahan dalam menentukan } \\
\text { apa yang diketahui oleh soal } \\
\text { 3. Kesalahan dalam menetukan } \\
\text { apa yang ditanyakan soal } \\
\text { 4. Kesalahan dalam membuat } \\
\text { pernyataan } \mathrm{n}=\mathrm{k}+1\end{array}$ \\
\hline
\end{tabular}




$\begin{array}{ll}\text { Kesulitan dalam persepsi visual } & \text { 1. Kesalahan membaca } \\ & \text { 2. Ketidak mampuan Mahasiswa } \\ & \text { dalam bernalar, ditentukan } \\ & \text { dengan wawancara }\end{array}$

\section{HASIL PENELITIAN}

Berikut adalah hasil penelitian pada kelas A angkatan 2017 Penelitian ini dimulai dari pemberian angket gaya belajar untuk mengetahui atau mengelompokkan Mahasiswa sesuai dangan gaya belajarnya kemudian dilanjutkan dengan tes hasil belajar untuk mengetahui kesulitan Mahasiswa dalam menyelesaikan soal matematika dengan materi induksi matematika dan tahap akhir peneliti melakukan wawancara kepada 2 Mahasiswa dari gaya belajar yang berbeda dengan beberapa pertimbangan yaitu (1) Mahasiswa tersebut adalah perwakilan dari setiap kelompok yang memiliki kesulitan terbanyak dalam mengerjakan soal (2) Mahasiswa tersebut mampu berkomunikasi dengan baik, setelah menimbang hal tersebut maka terpilihlah beberapa Mahasiswa yaitu S5, S17, S20 S22, S27,dan S32

\section{Analisis Angket Gaya Belajar}

Berdasarkan hasil angket gaya belajar pada kelas A angkatan 2017 diketahui jumlah subjek yang memiliki gaya belajar auditori pada kelas tersebut adalah 14 kemudian ada 12 subjek yang memiliki gaya belajar visual dan ada 10 subjek yang memiliki gaya belajar kinestetik

\section{Kesulitan Mahasiswa yang Bergaya Belajar Visual}

Berdasarkan analisis dari kesulitan dari 2 Mahasiswa yang bergaya belajar visual diketahui bahwa Mahasiswa tersebut mengalami kesulitan dalam mentransfer pengetahuan dan kemanpuan bahasa matematika yang kurang. Peneliti mengatakan subjek visual mengalami kesulitan dalam mentransfer pengetahuan karena Mahasiswa tersebut tidak mampu mensubsitusi suatu nilai kedalam persamaan, kemudian peneliti mengatakan 
subjek visual mengalami kesulitan dalam kemanpuan bahasa yang kurang karena ke2 subjek visual tersebut tidak mampu merumuskan formula $\mathrm{n}=\mathrm{k}+1$

Selanjutnya terkait kesulitan dalam kelemahan dalam berhitung subjek visual tidak mengalaminya walaupun dalam tes hasil belajar subjek visual menampakkan hal tersebut akan tetapi setelah di lakukan wawancara terkait hal tersebut disimpulkan bahwa kesalahan subjek visual dalam berhitung karena tergesah-gesah dalam menyelesaikan soal dan ketidakfokusnya subjek visual. Kemudian terkait kesulitan dalam presepsi visual, dari hasil analisis subjek visual tidak mengalaminya hal ini terbukti bahwa subjek visual mampu membaca soal dengan baik dan mengetahui beberapa materi prasyarat dari induksi matematika

\section{Kesulitan Mahasiswa yang Bergaya Belajar Auditori}

Berdasarkan analisia kesulitan ke2 subjek auditori mengalami kesulitan dalam kelemahan berhitung dan kemanpuan bahasa matematika yang kurang.Peneliti mengatakan subjek auditori mengalami kesulitan dalam kelemahan berhitung karena ketidak manpuan subjek auditori dalam mengoperasikan suatu bilangan dengan bilangan lainnya, baik dari hasil tes dan wawancara terlihat jelas bahwa subjek auditori tidak mampu mengoperasikan 2 bilangan pada saat mengandung variabel. Kemudian peneliti emngatakan subjek auditori mengalami kesulitan dalam kelemahan bahasa matematika yang kurang karena baik dari hasil tes subjek auditori tidak mampu merumuskan formula $\mathrm{n}=\mathrm{k}+1$ dan dalam wawancara saat peneliti memberikan kesempatan kepada subjek untuk merumuskan hal tersebut tetap saja subjek tersebut tidak bisa.

Selanjutnya terkait kesulitan dalam mentransfer pengetahuan, peneliti menyimpulkan bahwa subjek auditori tidak mengalami hal tersebut walaupun pada hasil tes dari subjek auditori menampakkan kesulitan tersebut akakn tetapi saat peneliti mengomfirmasi terkait hal itu pada sesi wawancara terlihat bahwa subjek auditori tidak nampak bahwa mengalami kesulitan dalam mentransfer pengetahuan. Kemudian terkait kesulitan dalam presepsi visual 
peneliti menyimpulkan bahwa subjek auditori tidak mengalami kesulitan tersebut karena subjek auditori mampu membaca soal dengan baik dan mengetahui beberapa materi prasyarat terkait induksi matematika.

\section{Kesulitan Mahasiswa yang Bergaya Belajar Kinestetik}

Berdasarkan analisis dari ke-2 subjek kinenstetik diketahui bahwa subjek kinestetik tidak memengalami kecenderungan kesulitan belajar, subjke S20 mengalami kesulitan dalam kelemahan berhitung dan kemanpuan bahasa matematika yang kurang sedangkan subjek S5 mengalami kesulitan dalam mentransfer pengetahuan.

Dari data yang diperoleh oleh peneliti terlihat bahwa S20 tidak mengalami kesulitan dalam mentransfer pengetahuan walaupun dalam lembar tes subjek S20 menampakkan kesulitan tersebut pada soal nomor 2 terkait subsitusi suatu pernyataan kedalam suatu persamaan namun saat di konfirmasi melalui wawancara terlihat bahwa subjek tersebut mengetahui indicator yang terdapat pada kesulitan mentransfer pengetahuan.

Kemudian dari data yang diperoleh dari S5 diketahui bahwa subjek tersebut tidak mengalami kesulitan dalam kelemahan berhitung hal ini dibuktikan pada sesi wawancara dan subjek tersebut mampu menyelesaikan soal yang diberikan saat sesi wawancara terkait operasi.

\section{KESIMPULAN}

Berdasarkan hasil penelitian dan pembahasan terkait profil kesulitan Mahasiswa Pendidikan Matematika dapat disimpulkan sebagai berikut: (1) Mahasiswa bergaya belajar visual mengalami kesulitan dalam menyelesaikan soal menurut tori martini yaitu kesulitan dalam mentransfer pengetahuan dan pemahaman bahasa matematika yang kurang. (2) Mahasiswa bergaya belajar auditori mengalami kesulitan dalam menyelesaikan soal menurut teori martini yaitu kelemahan dalam berhitung dan pemahaman bahasa matematika yang kurang dan (3) Mahasiswa bergaya belajar kinestetik mengalami kesulitan pada kelemahan berhitung, kesulitan dalam mentransfer pengetahuann dan pemahaman bahasa matematika yang kurang, artinya Mahasiswa bergaya 
belajar kinestetik tidak memiliki kecenderungan kesulitan dalam menyelesaikan soal.

\section{DAFTAR PUSTAKA}

Adhitya. 2015.Analisis Kesalahan Mahasiswa Smp Kelas Vii dalam Menyelesaikan Masalah Matematika Materi Segiempat Ditinjau dari Gaya Belajar. Jurnal Pendidikan Matematika, (Online). (https://lib.unnes.ac.id/, diakses 06 Desember 2018 pada pukul 12.41).

Afif, dkk. 2017.Analisis Kemampuan Penalaran Matematis Ditinjau dari Gaya Belajar Mahasiswa dalam Problem Based Learning (PBL). Seminar Nasional Matematika X Universitas Negeri Semarang 2016, (Online). (https://journal.unnes.ac.id/, diakses 06 Desember 2018 pada pukul 13.49).

Afifah, dkk. 2017. Penerapan Model Penemuan Terbimbing un tuk Meningkatkan Penalaran Matematika Mahasiswa. Jurnal Pembelajaran Matematika, ISSN(2087-913X). Nomor 1 Januari 2016.

Depdiknas. (2006). Permendiknas Nomor 22 Tahun 2006 Tentang Standar Isi Sekolah Menengah Pertama. Jakarta: Depdiknas

Kritanti. 2017. Analisi Kesulitan dan kemampuan Mahasiswa Dalam Menyelesaikan Soal Matematika Materi Kubus dan Balok pada Mahasiswa Kelas VIII A SMP Institut Indonesia Tahun Ajaran 2016/2017. Jurnal Pendidikan Matematika, (Online). (https://repository.usd.ac.id/, diakses 06 Desember 2018 pada pukul 13.20).

Martini, J. 2013. Kesulitan Belajar: Perseptif, Asesmen, dan Penanggulangannya. Bogor:Ghalia Indonesia.

Yudha, dkk. 2017.Identifikasi Gaya Belajar Matematika Mahasiswa Kelas VII di SMP Negeri 14 Malang. Skripsi, (Online). (http://jurnalonline.um.ac.id/, diakses 09Februari 2019 pada pukul 21.55). 